\author{
AMERICAN JOURNAL OF FOOD AND NUTRITION \\ Print: ISSN 2157-0167, Online: ISSN 2157-1317, doi:10.5251/ajfn.2013.3.3.105.116 \\ C 2013, ScienceHu $\beta$, http://www.scihub.org/AJFN
}

\title{
Characterisation of banana wine fermented with recombinant wine yeast strains
}

\author{
${ }^{1}$ Byaruagaba-Bazirake G.W.; ${ }^{2}$ Pierre. van Rensburg and ${ }^{3}$ W.Kyamuhangire \\ ${ }^{1}$ Food Technology Department,Kyambogo University,P.O.Box 7181,Kampala,Uganda E-mail: \\ gwbb@ymail.com ${ }^{2}$ Institute of Wine Biotechnology, University of Stellenbosch, Cape \\ Town,South Africa, E-mail: pvanrensburg@distell.co.za ${ }^{3} \mathrm{Food}$ Science and Technology \\ Department,Makerere,University,P.O.Box7062,Kampala,Uganda. \\ E-mail:wkyama@agric.mak.ac.ug \\ 1- Correspondence author.
}

\begin{abstract}
Commercial enzyme preparations are applied in the process of winemaking to improve wine processing and wine quality. In this study, three recombinant wine yeast strains that had been developed to improve wine processing were compared with regard to their ability to produce banana wine of an acceptable quality. The recombinant wine yeast strains contain genes coding for enzymes able to degrade different polysaccharides (glucan, xylan, pectin and starch). The recombinant strains were able to induce higher wine yields from the fermented banana pulp vis-àvis the control. The wines obtained with the recombinant strains and the untransformed control did not show significant differences $(p>0.05)$ in their physicochemical parameters. The highest wine yield obtained from the pulp which was treated with genetically modified yeast (recombinant yeast strain) secreting glucanase and xylanase enzymes (plasmid pDLG39) was $69.5 \% \mathrm{v} / \mathrm{w}$ prepared from Bogoya pulp. This wine yield was higher than the control yield $(65.9 \pm 0.07)$ by an increase of $5.5 \% \mathrm{v} / \mathrm{w}$. However, the wine from Kayinja pulp which was treated with genetically modified yeast secreting pectinase enzyme(plasmid pPPK) yielded wine $(60.3 \pm 0.28 \% \mathrm{v} / \mathrm{w})$ with $35 \%$ increase compared to the wine $(44.7 \pm 0.49)$ obtained with the control yeast. The recombinant yeast strains compared in this work secreted enzymes playing a similar role to that of the previously studied pectinolytic commercial enzymes. Therefore, such a recombinant yeast strain could be used in banana wine fermentations as an alternative to commercial enzyme preparations.
\end{abstract}

Key words: Recombinant yeast, pectinase, glucanase, xylanase, amylase, wine

\section{INTRODUCTION}

Biotechnology in general, and genetic engineering in particular, have in the recent few decades enabled gene manipulation and enhanced technologies in applied agricultural and food biotechnology research. These advances in DNA technology have made it possible to clone genes with traits of interest to the winemaker and to manipulate organisms' cells to overproduce the desired protein. During the last 18 years, several attempts to construct genetically engineered yeast strains have been published, and very interesting improvements in the wine-making process or the quality of the wine obtained have been reported, including improved primary and secondary flavors, malic acid decarboxylation by yeast, increased resveratrol, lactic acid, or glycerol contents, and improved survival properties (Barros et al., 2000; Dequin et al., 1999; Ganga et al., 1999; Gil and Valles, 2001; Gonzales-Candelas et al., 2000; Lilly et al., 2000; Perez-Torrado et al., 2002; Remize et al., 1999; Smit et al., 2003; Vilanova et al., 2000; Volschenk et al., 2001). Many enzymes have been expressed in manipulated micro-organisms at levels of 10 to 100 times higher than in their natural host cells (Kresse, 1995; 2001). The degradation of structural polysaccharides by carbohydrases can result in an improvement in juice yield, clarification and filterability during winemaking (Colagrande et al., 1994; Haight and Gump, 1994; Van Rensburg and Pretorius, 2000). Saccharomyces cerevisiae lacks the ability to produce extra cellular depolymerising enzymes that can efficiently liberate fermentable sugars from abundant, polysaccharide-rich 
substrates, and this limits $S$. cerevisiae to a narrow range of carbohydrates. A number of targets being set for the genetic improvement of wine yeasts. These targets include increasing the efficiency of the fermentation progress, the processing of wine and control of microbial spoilage, in addition to enhancement of wholesomeness and sensory quality (Henschke, 1997; Snow, 1983; Pretorius and Van der Westhuizen, 1991 Pretorius, 1999, 2000, 2001, 2002). Therefore, the exploitation of recombinant yeast strains with the ability to utilise such complex polysaccharides can aid in the cost-effective production of heterologous proteins of biological interest (Gundllapalli Moses et al., 2002). As an alternative strategy to the addition of costly enzyme preparations that often contain unwanted contaminating or side activities, wine yeasts are being developed to secrete proteolytic and polysaccharolytic enzymes that would remove hazeforming proteins and filter-clogging polysaccharides during fermentation. To this end, the overexpression of several bacterial, fungal and yeast genes has resulted in proteolytic, pectinolytic, glucanolytic and xylanolytic wine yeast strains (Querol and Ramon 1996; Pretorius, 1997; Van Rensburg and Pretorius, 2000; Gognies et al., 2001; Laing and Pretorius, 1993; Pérez-Gonzélez et al., 1993; Van Rensburg et al., 1998). To comply with the ever-increasing demands of modern winemakers and consumers for the best quality wine at every price point, it is also inevitable that novel enzymes will be designed for specific purposes and then tailored through protein engineering technologies (Van Rensburg and Pretorius, 2000).

In the previous chapters, we indicated that we were able to produce a stable banana wine of acceptable quality by applying different polysaccharidedegrading commercial enzymes during the winemaking process. As far as we know, this will be the first attempt to apply recombinant wine yeast strains for improved processing in banana wine production, with the aim also to produce a stable banana wine of acceptable quality.

\section{MATERIALS AND METHODS:}

Banana cultivars used: The two types of bananas used were kayinja, which was obtained from uganda, and williams of the same bogoya (gros michel) genotype, was bought from "fruit and veg city" in stellenbosch, south africa. the bananas in each set of experiments were ripened to stage 8 (yellow, speckled brown) of ripeness under special conditions, with temperatures ranging between 28 and $33^{\circ} \mathrm{C}$.
Yeast strains and plasmids: The control wine yeast strain was saccharomyces cerevisiae vin13 (from anchor yeast biotechnologies, south africa). vin13 is also the parent yeast that had been manipulated into the recombinant strains. the genotypes and phenotypes of the recombinant yeast used in this study are summarised in table 5.1.

Table 5.1: Recombinant wine yeast strains used in this study

\begin{tabular}{|c|c|c|c|}
\hline Plasmid & Phenotype & Genotype & Reference \\
\hline pPPK & Pectinolytic & 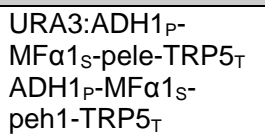 & $\begin{array}{l}\text { Louw et al., } \\
2006\end{array}$ \\
\hline pDLG31 & Amylolytic & $\begin{array}{l}\text { URA3::PGK1 }{ }_{\mathrm{P}} \\
\text { LKA1-PGK1T }\end{array}$ & $\begin{array}{l}\text { Gundllapalli } \\
\text { Moses et } \\
\text { al., } 2002\end{array}$ \\
\hline pDLG39 & $\begin{array}{l}\text { Glucanolytic } \\
\text { Xylanolytic }\end{array}$ & 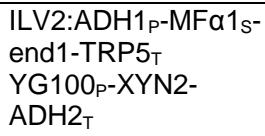 & $\begin{array}{l}\text { Louw et al., } \\
2006\end{array}$ \\
\hline
\end{tabular}

Culturing media and inoculation: The yeast was grown in yeast peptone dextrose (YPD) broth (1\% yeast extract, $2 \%$ peptone and $2 \%$ dextrose). To inoculate the cultures, $10 \mathrm{ml}$ of YPD medium was inoculated with a single selected colony of the desired yeast strains and incubated overnight at $30^{\circ} \mathrm{C}$. After incubation, $1 \mathrm{ml}$ of the yeast culture was introduced into $200 \mathrm{ml}$ YPD medium. The yeast cells were allowed to grow at a temperature of $30^{\circ} \mathrm{C}$ for three to four hours on a shaker. Then, after determining the yeast cell growth in the medium, the cells were centrifuged at $5000 \mathrm{rpm}$ for $5 \mathrm{~min}$ with a gforce of 2200. The pellets formed in the centrifuge tubes were re-suspended in $30 \mathrm{ml}$ of distilled water. The banana pulp was inoculated at $2 \times 10^{6}$ cells per $\mathrm{ml}$.

\section{Microvinification experiments: The fermentation}

fermentation assays were carried out using two different banana cultivars. The over-ripe bananas at stage 8 (yellow, speckled brown) were hand peeled and pulped using a motorised mixer. The banana pulp was measured in kilograms to determine the correct ratio of processing aids. After pulping, $50 \mathrm{ppm}$ of $\mathrm{SO}_{2}$ was added to the pulp. During these prefermentation operations, the pectinaceous nature (the thickness) of the banana pulp proved problematic (colloidal and viscous) to handle in pre-fermentation operations and the pulp was thus diluted with water in a ratio of 3:e 1 to reduce the viscosity of the pulp and 
make more liquid (juice-water mixture) available in the fermenting biomass. Diammonium phosphate (DAP) was applied to the pulp at a rate of $0.7 \mathrm{~g} / \mathrm{kg}$ to supplement the nitrogen required in alcoholic fermentation. The transformed recombinant (DNA) yeast strains and the untransformed (VIN13, control) yeast were used to inoculate the banana pulps in duplicates. The inoculated pulps were allowed to ferment at room temperature. The progress of the fermentation was monitored by measuring the weight loss per day until a constant weight was attained for three days. The Clinitest (Bayer Corporation, USA) method where reagent tablets are added in wine solution to estimate reducing sugars (in percentages) was used after no further weight loss was observed for three days. The wine yields in percentages volume by weight $(\% \mathrm{v} / \mathrm{w})$ was calculated by dividing the wine volume (litres) by the weight (kilograms) of the banana pulp inoculated with the volume of water used for dilution excluded.

\section{Wine stabilisation and filtration: After complete}

After complete fermentation, banana wine was extracted from the pulp, stabilised and filtered through $0.3 \mu \mathrm{m}$ filter pads treated with citric acid, with diatomaceous earth as a filter aid and at a pressure of $50-150 \mathrm{kPa}$ in a batch pressure filter. Various parameters were then analysed (see Table 5.3) in the sampled batches.

Physicochemical analyses of banana wine: The ph of the wine was measured by using a glass calomel electrode ph meter (cole parmer, vernon hills, il, USA). together with titratable acidity, the ph was determined again, this time automatically with a 20:702 sm titrino (metrohm). The soluble solids ('balling) in the wine were determined using a hydrometer as outlined by iland et al. (2000). reducing sugars $(\mathrm{g} / \mathrm{l})$ were analysed by means of the rebelein method, described by iland et al. (2000). volatile acidity (va) was determined by distillation in a b\&m scientific markham still. the free sulphur dioxide $\left(\mathrm{SO}_{2}\right)$ of the wine was determined by an iodine titration technique, using the ripper method as outlined by iland et al. (2000). The turbidity of the wine was measured using a hack turbidimeter and expressed in nephelometric turbidity units (ntu), while the alcohol content was measured in percentage volume by volume $(\% \mathrm{v} / \mathrm{v})$ by two methods, namely alcoholometry and ebulliometry as outlined by iland et al. (2000).

\section{RESULTS AND DISCUSSIONS}

Wine fermentation: All the various fermentations were completed on average in 15 days. All the wines that were produced contained less than $3 \mathrm{~g} / \mathrm{l}$ reducing sugars and can be considered as dry wines. No significant difference in fermentation performances were observed between the control yeast (vin13) and the recombinant (dna) yeast strains.

Wine yields: The pulps inoculated with genetically modified yeast yielded banana wine as presented in table 5.2. The wine yields were analysed statistically and the results are presented in figure 5.1 (a) and (b). The total bulk of kayinja bananas that was obtained from uganda had been peeled and yielded $60 \%$ of the fruits weight $(\mathrm{kg})$, and the rest $40 \%$ discarded in the form of peelings (waste). The highest wine yield $(60.3 \pm 0.28 \%)$ obtained in kayinja was from the pulp treated with yeast strain vin13-pppk, which phenotypically (table 5.1) had pectinolytic activity and yielded a percentage increase of $34.9 \%$ more wine than the control. The erwinia chrysanthemi pectate lyase gene (pele) and e.ycarotovora polygalacturonase gene (peh1) were each inserted between a yeast expression-secretion cassette and a yeast gene terminator in the plasmid pppk formation. pulps treated with strains vin13-pdlg31 (transformed with amylase coding gene) and vin13-pdlg39 (transformed with glucanase and xylanase coding genes) yielded $21.7 \%$ and $20.1 \%$ wine increases respectively more than the control (untreated pulp) from the kayinja cultivar. this elucidated that the main problematic polysaccharide in kayinja banana fruit is pectin compared to glucan and xylan and the most appropriate enzymes to degrade kayinja pulp would be pectinases.

In the case of Bogoya cultivar, the wine yield increases were approximately $1 \%, 1.4 \%$ and $5.5 \%$ with VIN13-pPPK, VIN13-pDLG31 and VIN13pDLG39 treated banana pulps respectively. The Kayinja banana cultivar showed a significant $(p<0.05)$ difference in the wine yields obtained from the pulps treated with recombinant yeast strains compare to the control. Bogoya cultivar showed only slight differences in wine yields between the recombinant yeast fermented pulps and the control. The difference in wine yields between the two types of bananas of different genotypes seems to indicate that the enzymes in the transformed yeast work better in Kayinja than in Bogoya. The polysaccharides in Bogoya seem to be more readily degraded at ripeness than in Kayinja as earlier discussed in chapter three. Even with no exogenous enzymes 
added (see control), the Bogoya cultivar yielded wine $(65.9 \%)$ close to the yields from recombinant yeast treated pulps. The endogenous enzymes in Bogoya seem to be very effective with little influence in wine yield effected by supplementary exogenous enzymes (particularly pectic and amylolytic) for further degradation of the polysaccharides in the pulp to yield wine. However, the yeast strain transformed with glucanase and xylanase coding genes (VIN13pDLG39) showed significant difference $(p<0.05)$ in Bogoya. This suggests that glucan and xylan (part of polysaccharides complex) in Bogoya require exogenous enzymes to supplement the endogenous enzymatic activities.

Viquez et al. (1981) reported that the addition of pectinase enzymes in the preparation of wines served to reduce viscosity, facilitated pressing of fermented solids and in so doing increased the yield. The results of wine yields in this study are in agreement with what Viquez et al. (1981) had earlier reported particularly in Kayinja cultivar where wine yields $(34.9 \%)$ were very significant.
Table 5.2: $\quad$ Wine yields from banana cultivars fermented with recombinant yeast strains.

\begin{tabular}{|l|l|l|}
\hline \multirow{2}{*}{ Yeast } & Cultivar & $\begin{array}{l}\text { Yield(\%v/w) } \\
\text { Mean } \pm \text { SD }\end{array}$ \\
\hline \multirow{2}{*}{ pPPK } & Kayinja & $60.3 \pm 0.28^{\mathrm{c}}$ \\
\cline { 2 - 3 } & Bogoya & $66.4 \pm 0.52^{\mathrm{d}}$ \\
\hline \multirow{2}{*}{ pDLG31 } & Kayinja & $54.4 \pm 0.07^{\mathrm{b}}$ \\
\cline { 2 - 3 } & Bogoya & $66.8 \pm 0.43^{\mathrm{d}}$ \\
\hline \multirow{2}{*}{ pDLG39 } & Kayinja & $54.0 \pm 2.12^{\mathrm{b}}$ \\
\cline { 2 - 3 } & Bogoya & $69.5 \pm 1.06^{\mathrm{e}}$ \\
\hline \multirow{2}{*}{$\begin{array}{l}\text { VIN13 } \\
\text { (Control) }\end{array}$} & Kayinja & $44.7 \pm 0.49^{\mathrm{a}}$ \\
\cline { 2 - 3 } & Bogoya & $65.9 \pm 0.07^{\mathrm{d}}$ \\
\hline
\end{tabular}

The wine yields are compared in Figure 5.2. Although the yields only showed big differences in Kayinja cultivar, the transformed wine yeast strains gave higher results than the control in both cultivars. Therefore, it can be concluded that the transformed yeast strains are suitable for juice and wine extraction from over-ripe bananas.

Bootstrap means

Vertical bars denote 0.95 bootstrap confidence intervals

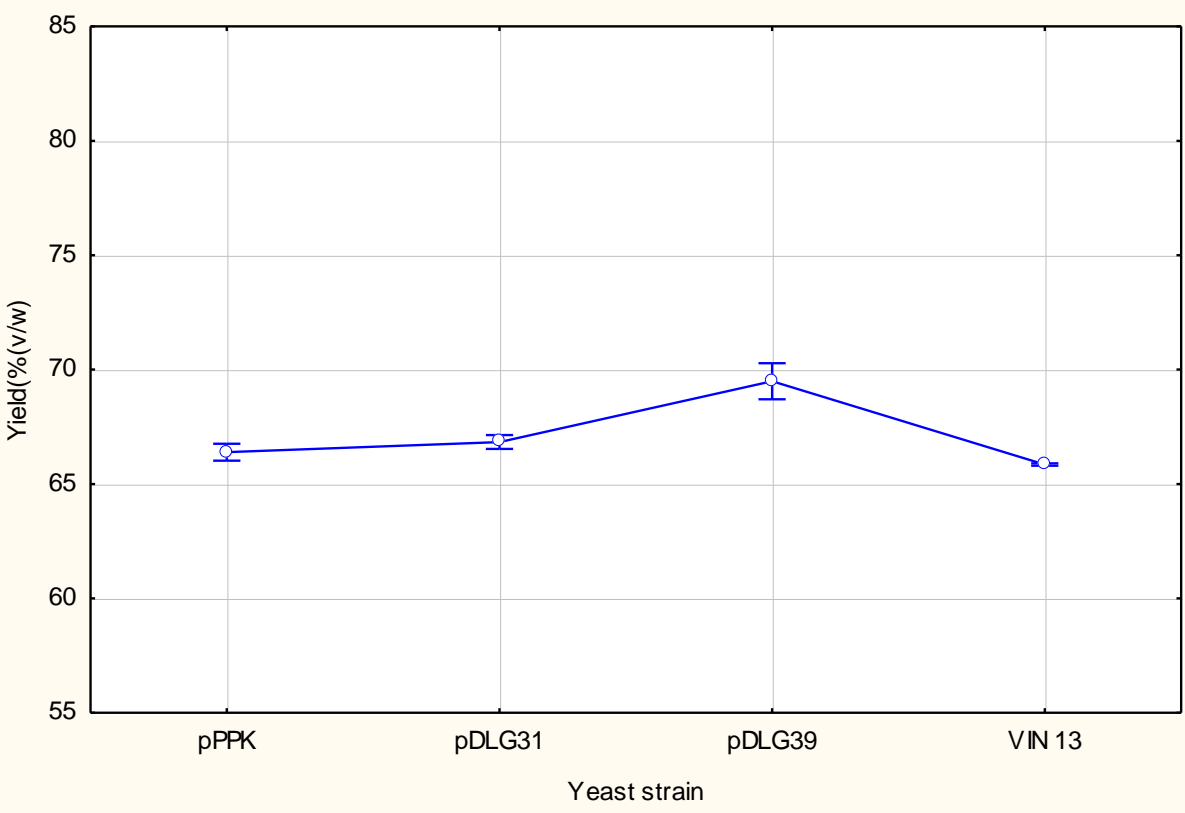

Fig 5.1 (a): Wine yields obtained from Bogoya (Musa AAA, genotype) pulps. 


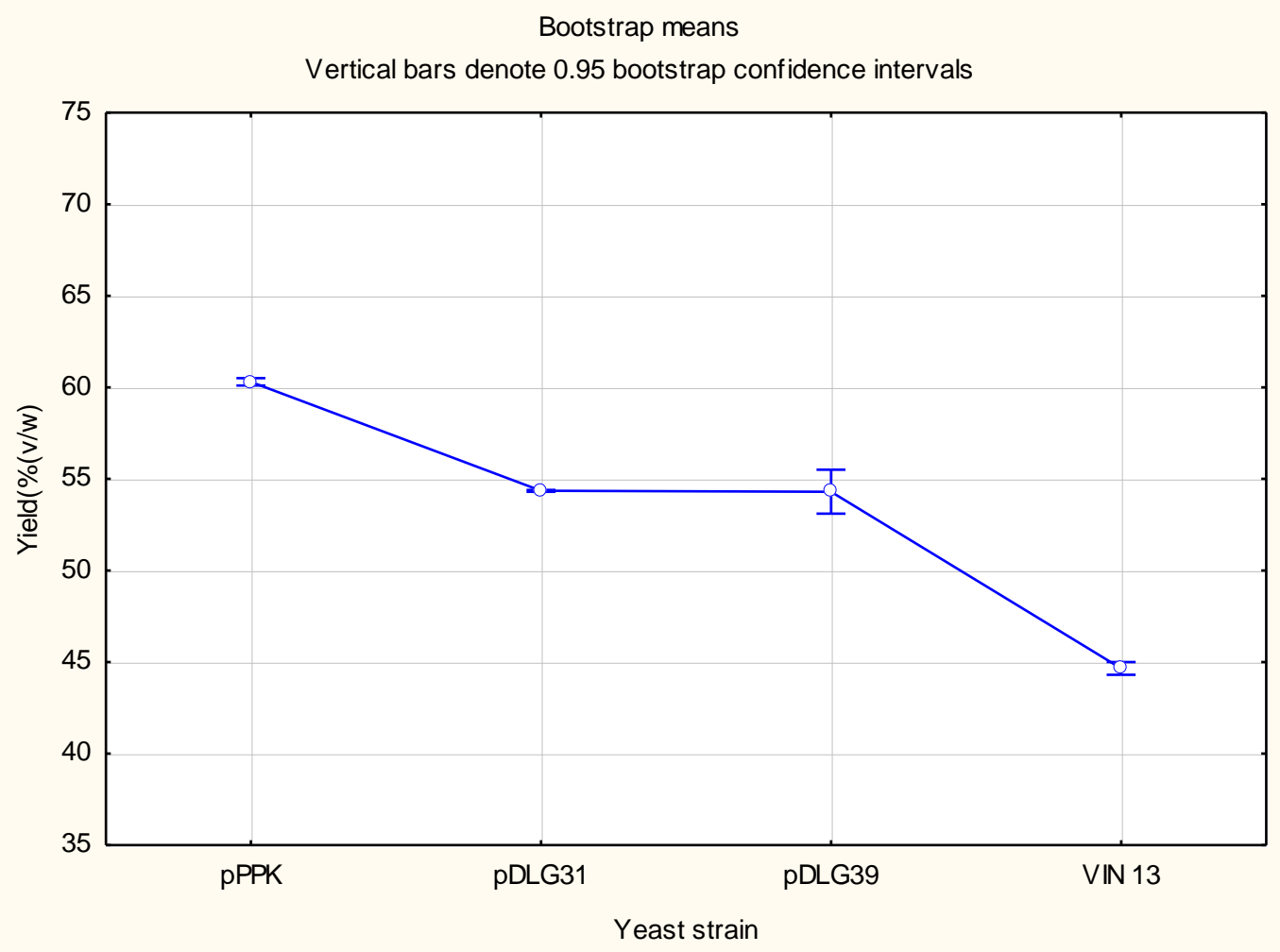

Fig 5.1 (b): Wine yields obtained from Kayinja (Musa ABB genotype) pulps.

Physicochemical analysis of banana wine: The physicochemical properties of the banana wines made using recombinant yeast strains are presented in Table 5.3.

\section{'Brix of juice obtained from the pulp}

The sugar content in terms of the total soluble solids of the juice was measured at $26.4^{\circ}$ Brix in Kayinja and $15^{\circ}$ Brix in Bogoya before dilution of pulp with water. The degrees Brix in Kayinja could potentially have produced an alcohol percentage of $15.05 \%$ (calculated as, $26.4 \times 0.57=15.05$ ), but practically gave a highest level of $9.9 \%(\mathrm{v} / \mathrm{v})$. The 0.57 as conversion factor was selected from the range (0.550.60 ) reported as experimental value measured in various studies on wines (Marsh, 1958; Ough and Amerine, 1963; Ough and Singleton, 1968; Jones and Ough, 1985). The final alcohol percentage obtained can be attributed to the dilution made which reduced the brix from 26.4 to $17.6^{0}$ Brix by the dilution ratio of $3: 1$. Secondly, whereas $90-95 \%$ of TSS is sugar (Margalit, 1997; lland et al., 2000), not all the sugar (about $8 \%$ ) is converted into ethanol. Margalit et al. (1997) stated that abut $5 \%$ of the sugar is consumed to produce by-products (glycerol, succinic acid, lactic acid, 2,3-butanediol,acetic acid, etcetera), about $2.5 \%$ is consumed by the yeast as a carbon source and about $0.5 \%$ are left over as unfermented residual sugars. And this explains why the actual alcohol content is always less than potential alcohol (based on theoretical calculations). The degrees brix in Bogoya were low $\left(15.7^{\circ} \mathrm{Brix}\right)$ on average. This could have resulted either from the bananas not being harvested at full maturity, or the banana stools grown under conditions that limited the sugar (TSS) formation in the fruits, for example, bananas grown under shade or in a cold climate. The low brix in Bogoya juice naturally gave a lower alcohol content (6.1-7.7\%) compared to Kayinja (8.5-9.9\%) (Table 5.3) in this study. 
Am. J. Food. Nutr, 2013, 3(3): 105-116

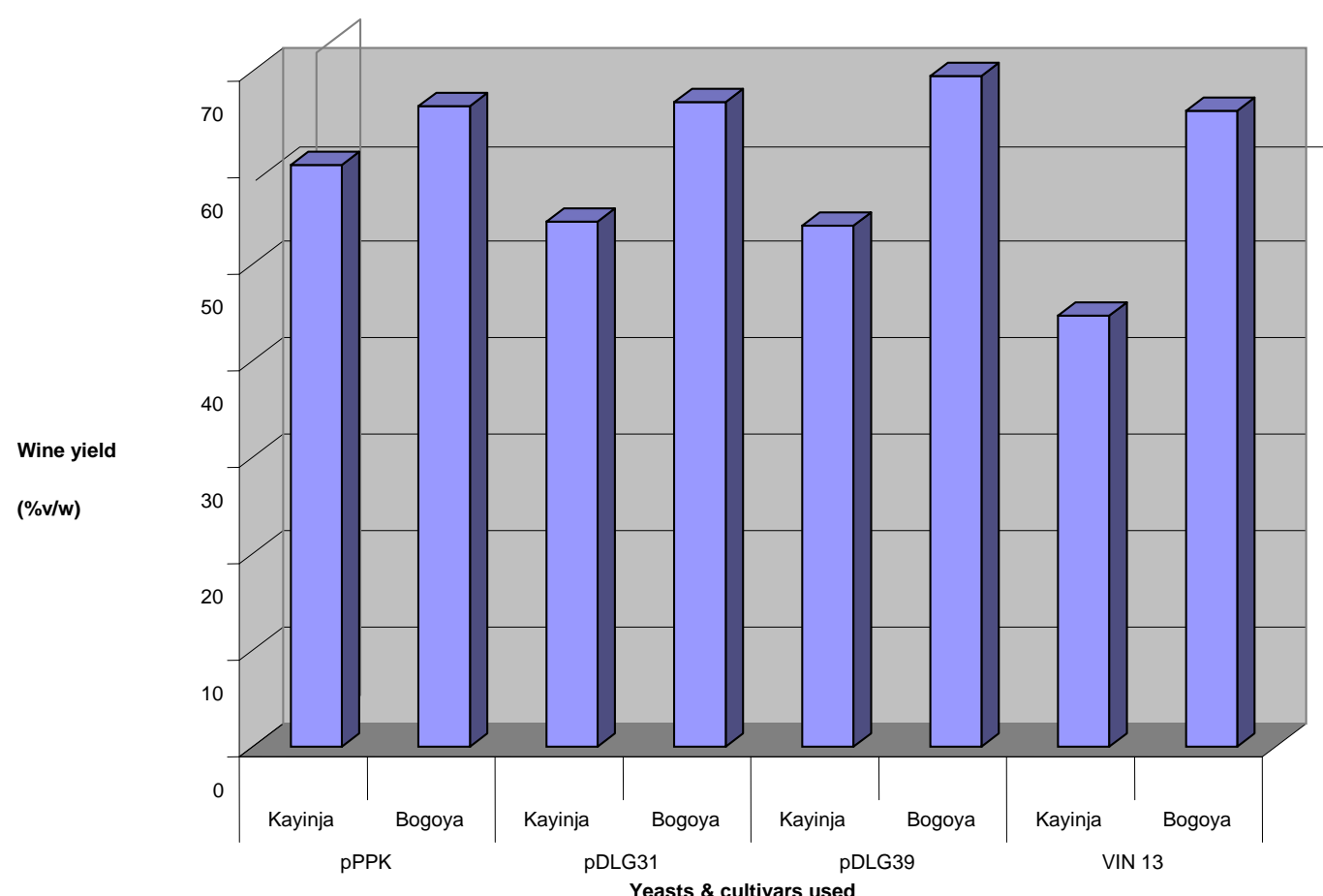

Fig 5.2: Wine yields (\%v/w) from Kayinja and Bogoya banana pulps fermented with recombinant yeast strains

Turbidity of the Wines: Whereas most of the parameters did not show significant differences $(p>0.05)$, the turbidity levels (NTU) remained significantly higher $(p<0.05)$ in the control (VIN13). This shows that the transformed yeast strains effectively used their enzymatic activities to play a similar role as that of the commercial enzymes and that they can act as substitutes for that purpose.

The fining and clarification of wine often include expensive and laborious practices that generate large volumes of lees for disposal, thereby causing a loss of wine and removing aroma and flavour compounds from the wine that remains. To minimize these disadvantages, an increasing spectrum of relatively expensive commercial enzyme preparations (proteases, pectinases, glucanases, xylanases and arabinofuranosidases) are frequently added to the grape must and wine.As an alternative to such preparations, which often contain unwanted contaminating or side activities, wine yeasts are being developed to secrete proteolytic and polysaccharolytic enzymes that would remove hazeforming proteins and filter-clogging polysaccharides respectively. To this end, the overexpression of several bacterial,fungal and yeast genes has resulted in proteolytic,pectinolytic,glucanolytic and xylanolytic wine yeast strains (Querol and Ramon 1996; Pretorius, 1997; Van Rensburg and Pretorius, 2000; Gognies et al., 2001; Laing and Pretorius, 1993; Pérez-Gonzélez et al., 1993; Van Rensburg et al., 1998). The results on turbidity in this study are in support of what the above researchers had noted and such means of improving processing efficiency in bananas should be exploited to greater heights.

In Figure 5.3 (a) and (b) it was shown how effective the recombinant yeast strains affected the turbidity in both cultivars compared to the control fermentation. Amylases and arabanase hydrolyse starch and araban in fruit juices respectively, thereby preventing potential turbidity in packaged juices and wines due to precipitation of such polymers (Uhlig, 1998). The same role on turbidity has been affected according to our results in Figure 5.3 (a) and (b). Also according to Sreekantiah (1975), the application of enzymes in the clarification of fruit juices and fruit wines aids in the partial or complete hydrolysis of the suspended 
starches, proteins and pectins. It appears that the amylases in their major role of hyrolysing starch, they also caused significant $(p<0.05)$ turbidity reduction in the banana wine.

Table 5.3: Physicochemical characteristics of banana wine fermented with recombinant (DNA) yeast strains.

\begin{tabular}{|l|c|c|c|c|}
\hline \multicolumn{1}{|c|}{ Cultivar/Parameter } & \multicolumn{3}{c|}{ Yeast plasmid/strain } & Control \\
\hline Bogoya (AAA) & pPPK & pDLG31 & pDLG 39 & VIN 13 \\
\hline TSS & 5.2 & 5.4 & 5.1 & 6.7 \\
\hline $\mathrm{pH}$ & 3.62 & 3.7 & 3.7 & 5.8 \\
\hline TA (g/L) & 6.7 & 5.6 & 6.47 & 0.58 \\
\hline VA (g/L) & 0.66 & 0.47 & 0.64 & 1.7 \\
\hline Reducing sugars (g/L) & 1.1 & 0.83 & 3.4 & 45 \\
\hline $\mathrm{SO}_{2} \mathrm{ppm}$ & 36 & 38 & 7.6 & 6.1 \\
\hline Alcohol (\%v/v) & 7.3 & 7.65 & 14.8 & 43.9 \\
\hline Turbidity (NTU) & 14.8 & 17.5 & & 7.15 \\
\hline Kayinja(ABB) & & & 5.2 & 4 \\
\hline TSS & 5.75 & 5.45 & 3.84 & 4.55 \\
\hline pH & 3.93 & 3.95 & 4.76 & 0.46 \\
\hline TA (g/L) & 5.59 & 4.44 & 0.59 & 2.34 \\
\hline VA (g/L) & 0.55 & 0.57 & 0.3 & 42 \\
\hline Reducing sugars (g/L) & 1.06 & 0.39 & 37 & 8.5 \\
\hline SO ${ }_{2}$ ppm & 32 & 34 & 9.9 & 51.95 \\
\hline Alcohol (\%v/v) & 9.4 & 9.8 & 22.21 & \\
\hline Turbidity (NTU) & 22.5 & 25.9 & & \\
\hline
\end{tabular}

Alcohol content in the wines: It was also elucidated that the alcoholic yield was higher when fermentation took place with the recombinant yeast in comparison to the control VIN13 yeast, as shown in Figures 5.4 (a) and (b) respectively. A comparison of the different recombinant yeasts shows that VIN13-pDLG39, which produces glucanolytic and xylanolytic enzymatic activities, was the best in influencing alcoholic fermentation. This highest alcohol content was obtained in Kayinja. Kayinja has higher sugars than Bogoya as earlier discussed in chapter three due to its high TSS (about $24-27^{\circ}$ Brix). When some of these polysaccharides are degraded, more sugars are released that can be converted to alcohol by the yeast and in this particular case glucans and xylans were degraded.

Wine analyses: The $\mathrm{pH}$ of the wines was higher in controls than in the wines obtained from enzyme treated banana pulps in both banana cultivars. The TA was more (except in Kayinja treated with
pDLG31) in recombinant yeast inoculated pulps. The VA in the wines was not higher in the wines obtained from enzyme-treated pulps except with VIN13PDLG31 which had VA of $0.47(\mathrm{~g} / \mathrm{L})$. It is difficult to explain why TA and VA were less than in the control wines when the recombinant yeast with the amylolytic-enzymatic activity was used. Perhaps the degraded starch affected the TA and VA in those wines. The resultant wines showed VA levels below the maximum of $0.7 \mathrm{~g} / \mathrm{L}$ allowed in grape wines. A high level of VA, which is an indication of microbial activity and by spoilage bacteria such $L A B$ and $A A B$, may also have detrimental effects upon the sensory quality of the wines. The reducing sugars remained the highest (Table 5.3) in the control wines in both cultivars. This means that recombinant yeast utilise the sugars more effective, which is difficult to explain since the control yeast is exactly the same except the one or two gene differences. The $\mathrm{SO}_{2}$ was higher in the control wines from the two cultivars. The use of 
the enzyme-secreting genetically modified yeasts improved the processing of the banana wines and displayed positive aspects, wine yield was improved, more alcohol was produced and the wine clarity was better compared to the control wines.

The GM yeast strains showed almost the same effect on turbidity. However, in both Bogoya and Kayinja, though not very significant, the wine obtained from pDLG31 treated pulp, which had the amylolytic activity had the highest values (that is 17.5 and 25.9 NTU respectively) compared to other wines obtained from the enzyme-treated banana pulps. The yeast strains transformed with pectinase, glucanse and xylanase showed approximately the same levels, i.e.about 15 NTU in Bogoya and 22.5 NTU in Kayinja. It may be surprising that amylases had the same effect on turbidity as the pectinase, glucanase and xylanase enzymes. It is well known that enzymes are ideal for breaking down soluble compounds responsible for high viscosity in upstream and downstream processes. Reaction efficiency, specific action, the ability to work under mild conditions and a high degree of purification and standardization all make enzymes ideal for the starch industry. One example of this application is in sweetener production where alpha-amylases reduce the viscosity of gelatinized starch. The thick gel can be transformed into a liquid that flows like water (for details on reduction of viscosity, see Olsen, 2000). Since ripe bananas contain 1-4\% starch, similar effects could have been caused amylolytic enzyme originating from the genetically modified yeast (VIN13-pDLG31) which was directly inoculated into pulp leading to viscosity and turbidity reduction. Such turbidity reduction by amylase and arabanase enzymes had been reported by Uhlig (1998).

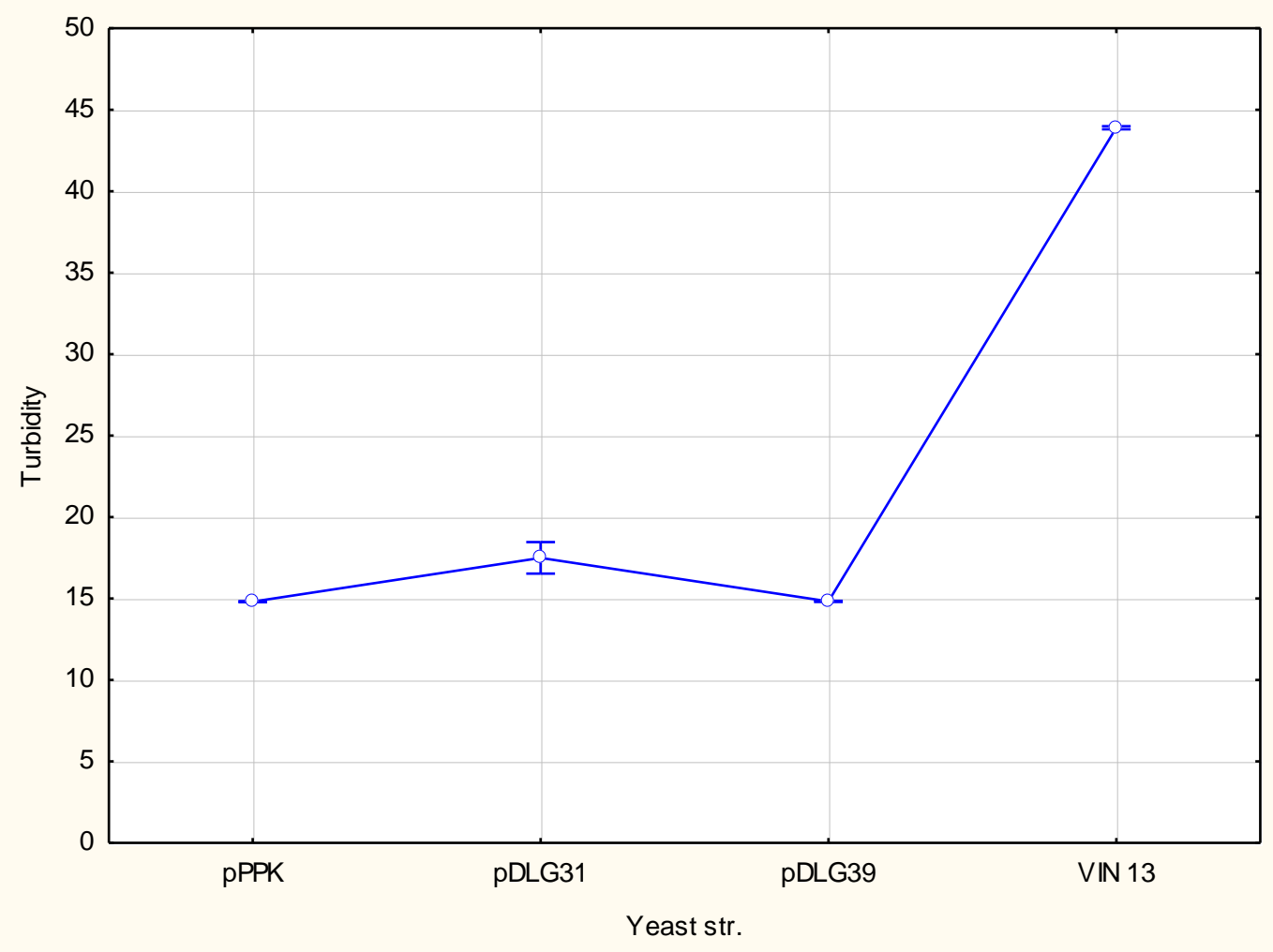

Fig 5.3 (a): The turbidity results of wines from the Bogoya cultivar fermented with recombinant yeast. 
Am. J. Food. Nutr, 2013, 3(3): 105-116

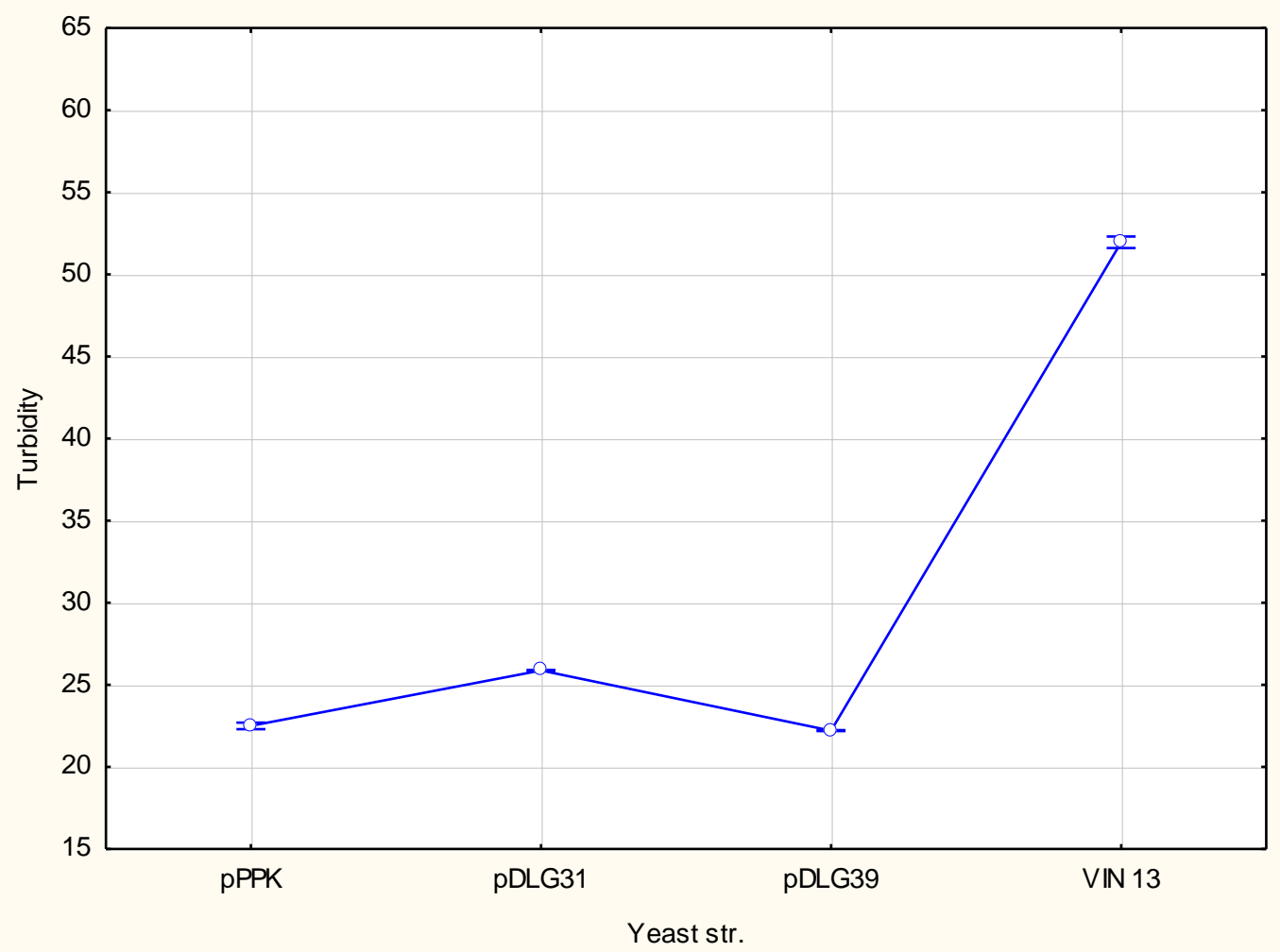

Fig 5.3 (b): The turbidity results of wines from the Kayinja cultivar fermented with recombinant yeast.

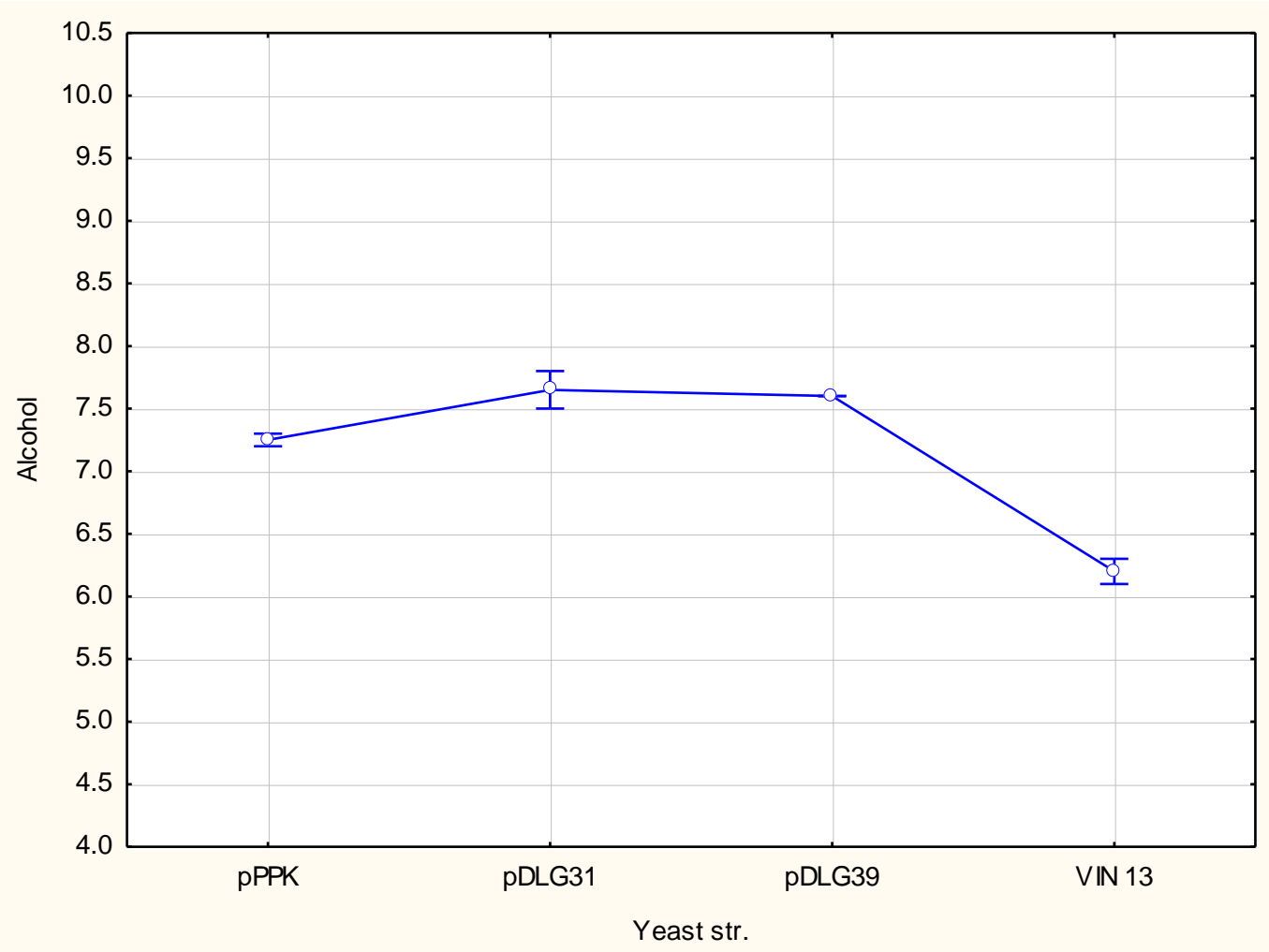

Fig 5.4 (a): Alcohol levels (\%v/v) obtained in Bogoya wines 


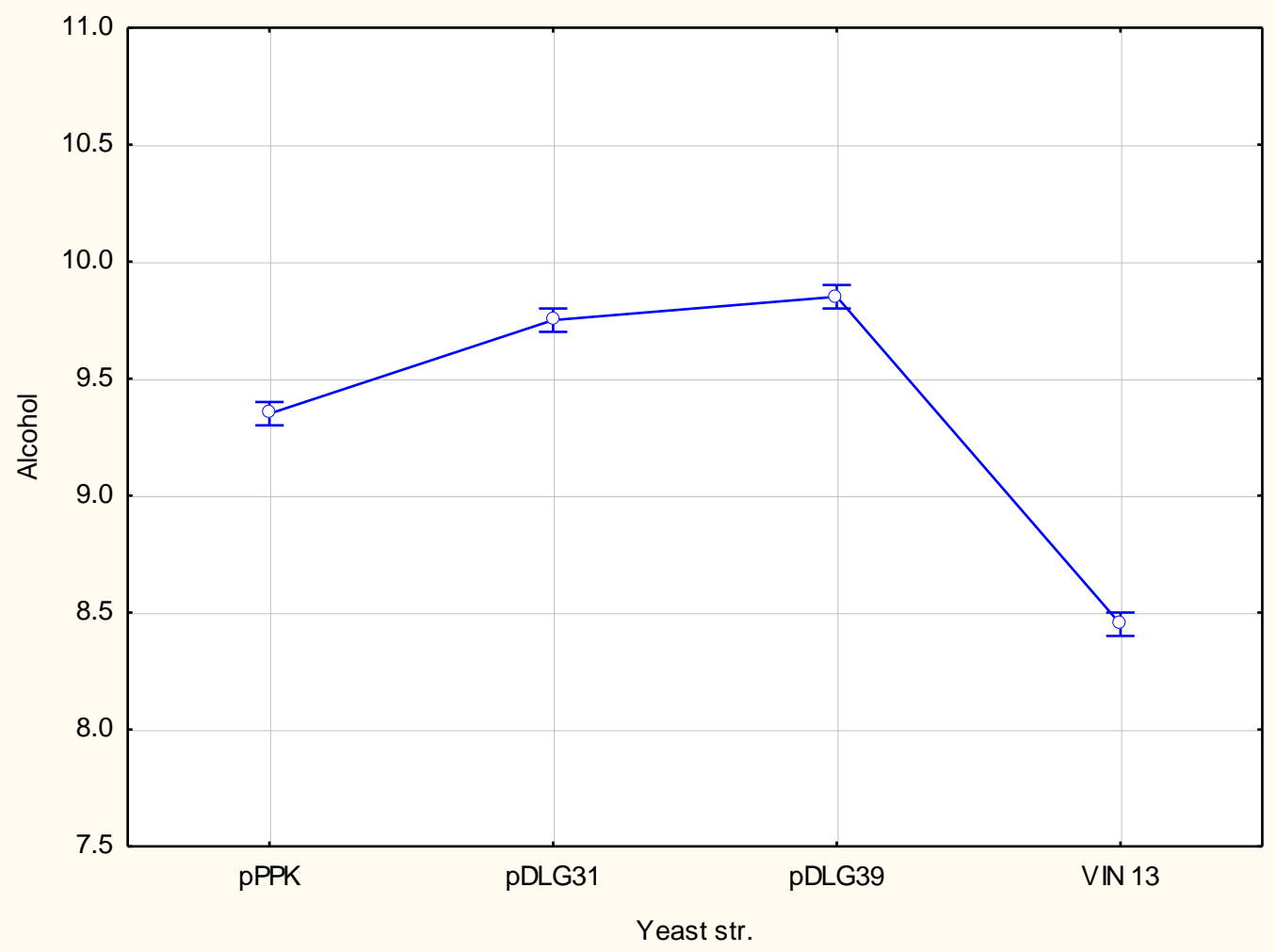

Fig 5.4 (b): Alcohol levels (\%v/v) obtained in Kayinja wines

In this study, stable wines were produced with the use of recombinant yeast strains.

It seems that using enzyme producing recombinant yeast was more effective compared to using the commercial enzymes on its own. In some cases the volume of wines obtained was more compared to the volume of juice extracted in Chapter 3 . This may due to longer reactic- 'ime during the fermentation compared to the $\mathrm{hr}$ incubation time with the commercial enzymes.

Kreuzer and Massey (2001), stated that the traits that are being introduced through genetic engineering are similar to those produced through selective breeding, and so the overarching concern about the safety of genetically engineered foods compared to our current foods is misplaced. The GM yeasts used in this study have been developed and used following the appropriate scientific protocols. As far as we know this is the first report of the use of recombinant yeast for the production of banana wine and may generate some information for further research and processing techniques in the field of biotechnology for production of novel foods.

\section{CONCLUSION}

The wines produced with the recombinant yeast definitively displayed some positive aspects. More wine was obtained compared to the control, more alcohol was obtained and the wine was much clearer than the control wine. The recombinant yeast strains moy serve as alternative to commercial enzymes in 1 cessing the banana wines. These recombinant yeast starter cultures could play an important role in rural areas, where it would be extremely difficult to store the various commercial enzymes under the correct conditions. They would also help to produce a less expensive, stable product from "waste" bananas. A further important analysis that still needs to be determined is whether the aromas and taste of the GM wine are similar or totally different from the nonGM produced banana wines.

\section{REFERENCES}

Barros Lopes, M., A. Rehman, H. Gockowiak, A. J. Heinrich, P. Landridge, and P. A. Henschke. 2000. Fermentation properties of a wine yeast overexpressing the Saccharomyces cerevisiae glycerol 3phosphate dehydrogenase gene (GPD2). Aust. J. 
Grape Wine Res. 6: 208-215.

Colagrande, O., Silva, A. and Fumi, M.D. 1994. Recent applications of biotechnology in wine productions. Biotechnology Progress 10: 2-18.

Dequin, S., E. Baptista, and P. Barre. 1999. Acidification of grape musts by Saccharomyces cerevisiae wine yeast strains genetically engineered to produce lactic acid. Am. J. Enol. Vitic. 50: 45-50.

Ganga, M. A., F. Piñaga, S. Valles, D. Ramón, and A. Querol. 1999. Aroma improving in microvinification processes by the use of a recombinant wine yeast strain expressing the Aspergillus nidulans $x \ln A$ gene. Int. J. Food Microbiol. 47: 171-178.

Gil, J. V., and S. Valles. 2001. Effect of macerating enzymes on red wine aroma at laboratory scale: exogenous addition or expression by transgenic wine yeasts. J. Agric. Food Chem. 49: 5515-5523.

Gonzalez-Candelas, L., J. V. Gil, R. M. Lamuela-Raventos, and D. Ramon. 2000. The use of transgenic yeasts expressing a gene encoding a glycosyl-hydrolase as a tool to increase resveratrol content in wine. Int. J. Food Microbiol. 59: 179-183.

Gognies, S. Simon, G. and Belarbi, A. 2001. Regulation of the expression of endopolygalacturonase gene PGU1 in Saccharomyces. Yeast 18: 423-432.

Gundllapalli Moses, S.B., Cordero Otero, R.R., La Grange, D.C., Van Rensburg, P. and Pretorius, I.S. 2002. Different genetic backgrounds influence the secretory eX-pression of the LKA1-encoded Lipomyces kononenkoae $\alpha$-amylase in industrial strains of Saccharomyces cerevisiae. Biotechnology Letters 651: 651-656.

Haight, K.G. and Gump, B.H. 1994. The use of macerating enzymes in grape juice processing. American Journal of Enology and Viticulture 25: 113-116.

lland, P., Ewart, A., Sitters, J., Markides, A. and Bruer, N. 2000. Techniques for chemical analysis and quality monitoring during winemaking. Patrick lland Wine Promotions, Australia 5074, p.70.

Jackson, T. and Badrie, N. 2002. Quality changes on storage of Caribbean banana (Musa acuminata) wines: Effects on pectolase concentration and incubation period. Journal of Wine Research 13: 46.

Jones, R.S .and Ough, C.S. 1985. "Variations in percent ethanol (v/v) per brix conversions of wine from different climate regions"- Am. J. Enol. Vit. 36: 268.

Kresse, G-B. 1995 (2 ${ }^{\text {nd }}$ Ed.). Biotechnology: Enzymes, Biomass, Food and Feed. EC-Joint Research Centre 1-21020 Ispara (VA) p. 161.

Kresse, G-B. 2001.Recombinant proteins of high value. In: Ratledge, C. and Kristianse, B. 2001. Basic Biotechnology, p. 430.
Kreuzer, H. and Massey, A. 2001. Recombinant DNA and Biotechnology: A guide for students. $2^{\text {nd }}$ Ed. American Society for Biotechnology, Washington, DC. p.39.

Laing, E. and Pretorius, I.S. 1993. Co-expression of Erwinia chrysanthemi pectate lyase encoding gene (pelE) and Erwinia carotovora Polygalacturonase encoding gene (peh1) in Saccharomyces cerevisiae. Appl. Microbiol. Biotechnol. 39:181-188.

Lilly, M., M. G. Lambrechts, and I. S. Pretorius. 2000. Effect of increased yeast alcohol acetyltransferase activity on flavor profiles of wine and distillates. Appl. Environ. Microbiol. 66: 744-753.

Louw, C., La Grange, D., Pretorius, I.S. and Van Rensburg, P. 2006. The effect of polysaccharide-degrading wine yeast transformants on the efficiency of wine processing and wine flavour. J. Biotech. 125: 447-461.

Margalit, Y. 1997. Concepts in wine chemistry. The Wine Appreciation Guild Ltd, 360 Swift Avenue, South San Francisco, CA 94080.

Marsh, G.L. 1958. Alcohol yield: factors and methods -Am. J. Enol. Vit. 9: 53.

Oslen, H.S. 2000. Enzymes at work - A concise guide to industrial enzymes and their use. Novozymes A/S, Bagsvaerd, Denmark.

Ough, C.S. and Amerine, M.A. 1963. Regional, varietal and type influences on degree Brix and alcohol relationship of grape musts and wines -Hilgardia $34: 585$.

Ough, C.S. and Singleton, V.L. 1968. Wine quality prediction from juice Brix/acid ratio and associated copmpositional changes for Riesling and Cabernet Sauvignon. Am. J. Enol. Vit. 19 : 129.

Pérez-González, J.A., González, R. Querol, A., Sendra, J. and Ramon, D. 1993. Construction of recombinant wine yeast strain expressing $B-(1-4)$-endoglucanase and its use in microvinification processes. Appl. Environ. Microbiol .59: 2801-2806.

Perez-Torrado, R., J. V. Gimeno-Alcañiz, and E. Matallana. 2002. Wine yeast strains engineered for glycogen overproduction display enhanced viability under glucose deprivation conditions. Appl. Environ. Microbiol. 68: 3339-3344.

Pretorius, I.S. and Van der Westhuizen, T.J. 1991. The impact of yeast genetics and recombinant DNA technology on the wine industry. S. Afr. J. Enol. Vitic. 12: 3-31.

Pretorius, I.S.1997.Utilization of polysaccharides by Saccharomyces cerevisiae.In:Yeast sugar metabolism (Zimmermann,F.K.and Entian,K-D.,eds) pp.459501.Technomic Publishers Co.

Pretorius, I.S. 1999. Engineering designer genes for wine yeast. Austr. N.Z. Wine Indust.J. 14: 42-47. 
Pretorius, I.S.2000. Tailoring wine yeast for the new millennium: Novel approaches to the ancient art of winemaking. Yeast, 16: 675-729.

Pretorius, I.S.2001.Genetic technology in winemaking: new approaches to an ancient art. Agric. Consp. Sci. 66: 120.

Pretorius, I.S.2002.The genetic analysis and improvement of wine yeasts. In: Fungal Biotechnology (Arora ,D.ed.) Marcel Decker (in press).

Querol, A. and Ramon, D. 1996. The application of molecular techniques in wine microbiology. Trends Food Scl. Technol. 7: 73-78.

Remize, F., J. L. Roustan, J. M. Sablayrolles, P. Barre, and S. Dequin. 1999. Glycerol overproduction by engineered Saccharomyces cerevisiae wine yeast strains leads to substantial changes in by-product formation and to a stimulation of fermentation rate stationary phase. Appl. Environ. Microbiol. 65: 143149.

Smit, A., R. R. Cordero-Otero, M. G. Lambrechts, I. S. Pretorius, and P. van Rensburg. 2003. Enhancing volatile phenol concentrations in wine by expressing various phenolic acid decarboxylase genes in Saccharomyces cerevisiae. J. Agric. Food Chem. 51: 4909-4915.

Snow, R. 1983. Genetic improvement of wine yeast. In: Spencer, J.T.F; Spencer, D.M. and Smith, A.R.W (eds).Yeast Genetics-Fundamental and Applied Aspects.Springer-Verlag, New York. pp. 439-459.
Sreekantiah, R.K. 1975. Nature and application of pectinases with special reference to fruit and vegetable processing industry, Indian Food Packer, 29: 22-25.

Uhlig H. 1998. Industrial enzymes and their applications. John Wiley \& Sons. Inc. Canada.

Van Rensburg, P. and Pretorius, I.S. 2000. Enzymes in winemaking: harnessing natural catalysts for efficient biotransformations - a review. S. Afr. J. Enol. Vitic. 21: 52-73.

Van Rensburg, P. Van Zyl, W. H. and Pretorius,I.S. 1998. Engineering yeast for efficient cellulose degradation. Yeast, 14: 67-76.

Vilanova, M., P. Blanco, S. Cortes, M. Castro, T. G. Villa, and C. Sieiro. 2000. Use of a PGU1 recombinant Saccharomyces cerevisiae strain in oenological fermentations. J. Appl. Microbiol. 89: 876-883.

Viquez, F., Lastreto, C. and Cooke, R.D. 1981. A study of the production of clarified banana juice using pectinolytic enzymes. J. of Food Technol. 16: 115-125

Volschenk, H., M. Viljoen-Bloom, R. E. Subden, and H. J. J. van Vuuren. 2001. Malo-ethanolic fermentation in grape must by recombinant strains of Saccharomyces cerevisiae. Yeast 18: 963-970.

Zoecklein, B. W., Fugelsang, K. C., Gump B. H. and Nury, F. S. 1995. Wine analysis and production.Chapman and Hall Enology Library, New York, pp. 97-301. 